\title{
Pengaruh Youtube Advertising terhadap Brand Awareness dan Purchase Intention
}

\author{
Dessy Yunita*, Ahmad Nazaruddin, Welly Nailis \\ Fakultas Ekonomi, Universitas Sriwijaya, Palembang \\ *dessyyunita@unsri.ac.id
}

\begin{abstract}
This study aims to examine the influence of YouTube Advertising on brand awareness and purchase intention. This study uses a conclusive design with single cross sectional. The number of samples are 210 respondents who watched advertisements on Youtube as research objects. Entertainment, informativeness, irritation, credibility, brand awareness and purchase intention are used to discuss the results of research. The results of this study show that the Youtube Advertising dimension does not influencee brand awareness, but brand awareness has impact on purchase intention.
\end{abstract}

Keywords : Brand Awareness, Credibility, Entertainment, Informativeness, Irritation, Purchase Intention

\section{PENDAHULUAN}

Era digital mengubah pola perilaku konsumen terutama dalam mengakses informasi. Sinergi antara industri telekomunikasi, perangkat telekomunikasi dan jaringan telekomunikasi membawa konsumen ke era komunikasi yang interaktif. Fakta menunjukkan bahwa masyarakat lebih banyak menghabiskan waktu mengakses segalanya secara digital. Selain itu, perangkat seluler telah mengubah cara individu berkomunikasi dan berinteraksi. Perangkat dan sistem berbasis teknologi seluler telah menjadi hal yang biasa dalam kehidupan kita sehari-hari sekarang ini (Balasubramanian, Peterson, \& Jarvenpaa, 2002). Tidak hanya itu, teknologi seluler juga berdampak kuat pada bisnis modern, aktivitas jauh lebih efesien (Balasubramanian et al., 2002). Teknologi seluler memiliki potensi untuk menciptakan pasar baru, mengubah sudut pandang persaingan bisnis, dan mengubah struktur masyarakat dan pasar yang ada (Stewart \& Pavlou, 2002). Penggunaan telepon selular melibatkan sekumpulan aplikasi dan layanan yang baru yang dapat diakses individu dari perangkat seluler mereka yang didukung web (Venkatesh, V., Ramesh, V. and Massey, 2003).

Saat ini, popularitas website dalam industri e-commerce berkembang pesat. Perkembangan teknologi informasi dan komunikasi tersebut, meningkatkan interaksi yang lebih mudah dan cepat antara pelanggan dan pengiklan. Informasi lebih cepat diperoleh melalui media digital. Pengguna internet akan lebih mudah melakukan reaksi terhadap aktivitas yang dilakukan melalui internet. Pengguna dapat langsung membuka website yang menyediakan informasi melalui media tersebut. Pihak perusahaan pun sekarang mulai menyesuaikan terhadap perubahan ini, 
termasuk didalamnya menambah saluran iklan secara digital. Aktivitas pemasaran yang dilakukan oleh perusahaan terutama di bidang iklan memanfaatkan media digital dengan memasang aplikasinya dalam beberapa konten popular. Dampaknya, perusahaan yang modern semakin mengandalkan fasilitas teknologi interaktif untuk mengiklankan dan mempromosikan produk dan layanan mereka (Pavlou \& Stewart, 2000).

Semakin meningkatnya pengguna perangkat seluler dalam aktvitas kesehariannya di banding mengakses media lainnya seperti televisi mendorong perusahaan menciptakan strategi melalui mobile advertising. Menurut data dari APJII pengguna internet di Indonesia sebesar 143,26 juta jiwa (Setiawan, 2017). Tingginya intensitas penggunaan media digital tersebut, bisa memberikan gambaran kesempatan yang jauh lebih efektif bagi perusahaan dalam penghematan biaya memasang iklan. Perusahaan akan lebih mudah mengukur jumlah penontonnya dan jauh lebih murah dengan memasang saluran pemasaran (beriklan) secara digital. Di televisi perusahaan membayar per detik per sekali tayang, tetapi melalui media digital perusahaan membayar per 100.000 viewers untuk biaya yang jauh lebih murah (kompas.com, 2018)

Berdasar hal tersebut, perancang iklan mulai melakukan strategi baru dengan menggunakan media baru yaitu internet sebagai media untuk menyampaikan iklan. Salah satunya dilakukan melalui Youtube. Youtube dianggap memiliki potensi yang besar bagi pengiklan, mengingat Youtube memiliki segmen yang lebih pasti. Youtube dengan penyedia layanan video terbesar sekarang ini dimiliki oleh Google, dimana pengguna bisa memuat, melihat dan berbagi video secara gratis dengan konten beragam. Melalui Youtube pengguna juga bisa mencari berbagai informasi dengan cara melihat tayangan. Tidak hanya itu, Youtube dimanfaatkan bukan sekedar hiburan tetapi juga interaksi sosial dalam bentuk komentar, mencari, serta memberikan informasi sebagai daya tariknya (Khan, 2017). Menurut Direktur Pemasaran Google, Indonesia memiliki tingkat pertumbuhan menonton video tertinggi sebanyak $130 \%$ dimana $60 \%$ diakses melalui perangkat seluler (Kompas.com, 2016). Pengguna lebih menyukai perangkat seluler karena memiliki privasi. Menurut Vice President of Engineering Youtube, Cristos Goodrow mengatakan bahwa durasi orang menonton video di platform meningkat drastis yang mencapai 1 miliar jam per hari. Hal ini menandakan bahwa orang menonton Youtube sekitar 1 jam video per hari (kompas.com, 2018)

Efektifitas mobile advertising bisa menghasilkan unsur faktor informativeness, credibility, entertainment, dan irritation sehingga diharapkan mampu untuk mempengaruhi brand awareness dan purchase intention. D. A. Aaker \& Bruzzone (1985), Youtube memiliki beberapa tipe mobile advertising, sebagai berikut:

1. Display Ads: iklan yang muncul berada di bagian samping kanan atas barisan rekomendasi video.

2. Sponsore Overlay Ads: iklan berbentuk transparan yang muncul di bagian bawah videocards yang menunjukkan konten products featured yang berhubungan dengan video.

3. Skippable Video ads dan Non-Skippable Video atau yang biasa disebut dengan Preoll Advertising: iklan ini muncul sebelum video yang ingin ditonton berputar, sehingga kita menunggu 5 detik untuk di skip. Sedangkan untuk yang nonskippabe tidak dapat langsung di skip penonton harus melihat keseluruhan iklan yang kira-kira baru bisa di skip beberapa menit.

Seperti yang diketahui biaya promosi adalah salah satu elemen yang membutuhkan biaya yang besar. Bentuk alternatif yang perlu ditempuh untuk tetap menggunakan sosial media atau yang yang sejenis, misalnya dengan menggunakan Youtube. Untuk ini, pemasar perlu memahami dan mengevaluasi bentuk saluran komunikasi yang dipilih melalui media digital secara 
efesien. Pemasar perlu memahami persepsi dari individu dengan melihat faktor dalam mobile advertising (informativeness, credibility, entertainment, dan irritation) apakah mempengaruhi penonton terhadap brand awaren

Youtube adalah perusahaan berbasis digital yang menyediakan informasi berbasis simpan dan berbagi video kepada pengunjungnya. Pengguna Youtube di Indonesia termasuk dalam kategori yang besar. Tentunya hal ini bisa dimanfaatkan sejumlah pengguna atau perusahaan untuk beriklan secara mobile. Mobile advertising memiliki banyak keuntungan antara lain dari sisi biaya yang lebih efisien dan tersegmen. Tetapi perlu diperhatikan bahwa terdapat faktor yang didapat dari mobile advertising yaitu faktor informativeness, credibility, entertainment, dan irritation yang menentukan keberhasilan dari mobile advertising

Penelitian ini bertujuan untuk mengukur respon konsumen terhadap dampak yang didapat dari Youtube Advertising terhadap brand awareness dan purchase intention. Penelitan ini akan menguji apakah ada pengaruh aspek Youtube Advertsing yaitu informativeness, credibility, entertainment, dan irritation terhadap brand awareness dan purchase intention.

\section{Komunikasi}

Komunikasi pemasaran berfokus pada pengukuran pencapaian tujuan pemasar mengikuti suatu proses khusus di mana pemasar mengambil tindakan dan konsumen merespons. Mobile marketing memberikan peluang yang baik bagi sebuah bisnis. Aktivitas pemasaran yang didukung oleh perangkat selular memungkinkan perusahaan untuk berkomunikasi secara langsung dengan konsumen mereka tanpa hambatan waktu atau lokasi. Mobile marketing ditujukan kepada konsumen dengan pesan iklan individual melalui perangkat seluler. Dalam perilaku pembelian dan pemilihan terhadap sebuah produk, nilai produk dianggap sebagai pengaruh yang penting (Zeithaml, 1988). Begitu juga dengan nilai dari sebuah iklan, juga mempengaruhi respons dari konsumen (Limbu, Huhmann, \& Peterson, 2012). Dalam beberapa teori menurut (Lutz, MacKenzie, and Belch 1983, Moore and Hutchinson, 1983, Silk and Vavra 1974) dalam (D. A. Aaker \& Bruzzone, 1985) mengatakan bahwa perilaku yang muncul ketika iklan ditayangkan adalah semakin mereka menyukai iklan yang ditayangkan, semakin mereka menyukai merk produk tersebut.

\section{Mobile Advertising}

Mobile Advertising dapat diartikan bentuk iklan atau pesan pemasaran yang disampaikan melalui perangkat portabel, telepon seluler, perangkat digital pribadi (Linn Fingalsson, Katalina Palma, 2015). Perangkat mobile sekarang mempunyai kekuatan dan berguna semenjak kehadiran dari sosial media secara mobile. Mobile sosial media memungkinkan pengguna menggunakannya kapan dan dimana saja. Semenjak pengguna memakai mobile device seperti Facebook, Twitter, Tumblr, Youtube, Instagram, aplikasi tersebut sangat mudah untuk diakses dan memuat informasi yang terus berubah.

Internet menjadi lebih menghibur dan memuat banyak informasi. Hal ini juga berpengaruh pada periklanan secara online yang terbuka bagi pemasar sehingga iklan dapat disesuatkan dengan klasifikasi individu berdasarkan karakteristik produk yang digunakan oleh mereka. Dalam literatur pemasaran terdapat 4 konten pesan untuk mengukur iklan pada mobile advertising (Haghirian, Madlberger, \& Tanuskova, 2005) (Dehghani, Niaki, Ramezani, \& Sali, 2016) yaitu:

\section{Informativeness}

Iklan yang bersifat informatif bila terdapat pesan dan konten yang berisi informasi. Tingkat pengetahuan pengguna mobile advertising akan menjadi lebih baik dengan menangkap pesan iklan yang informatif. Informativeness bisa juga dikatakan sebagai kemampuan sebuah iklan untuk memberikan informasi mengenai produk serta alternatifnya, 
sehingga bisa memberikan kepuasan kepada pelanggan pada saat melakukan pembelian sebuah produk. Kualitas informasi yang ditempatkan di situs web perusahaan memiliki pengaruh langsung pada persepsi pelanggan terhadap perusahaan dan produk perusahaan (Haghirian et al., 2005). Informasi dianggap sebagai insentif yang sangat berharga dalam mobile advertising, karena penerima bereaksi positif terhadap iklan yang memberikan keuntungan (Varshney \& Vetter, 2002).

\section{Credibility}

Ketika pesan dan informasi sebuah iklan dipercaya oleh pelanggan, maka pelanggan akan lebih memperhatikan iklan tersebut. Credibility dalam iklan memberikan dampak positif secara langsung terhadap evaluasi dari pelanggan (K. Y. Choi, Hwang, \& McMillan, 2010). Menurut (Mackenzie, Lutz, Belch, \& Mackenzie, 1989) mendefinisikan kredibilitas iklan sebagai "persepsi konsumen tentang kebenaran dan kepercayaan dari iklan secara umum". Jadi dapat dikatakan bahwa 4 (empat) konten pesan diatas ditentukan sebagai titik awal untuk memperhitungkan bagaimana konsumen menilai sebuah iklan (Ducoffe, 1995).

\section{Entertainment}

Entertainment merupakan hiburan yang bisa memenuhi kebutuhan pelanggan secara emosional, pengalihan perhatian dan estetika (McQuail, 2010). Unsur hiburan menandakan keahlian sebuah iklan memenuhi kebutuhan emosional dan estetika konsumen. Entertaiment pada sebuah iklan juga dapat merupakan hal yang memberikan rasa positif terhadap merek. Ketika iklan menawarkan nilai entertainment yang tinggi kepada pelanggan, maka hal tersebut akan mempermudah pelanggan untuk terus menggunakan media tersebut. Hiburan merupakan faktor penting untuk mobile advertising. Iklan yang yang dianggap menghibur, lebih mudah untuk mendapatkan perhatian konsumen.

\section{Irritation}

Ketika iklan menggunakan teknik yang menyebalkan dan terlalu memaksa pelanggan untuk membeli atau menggunakan produk yang diiklankan, kemungkinan kecil pelanggan memandang iklan tersebut dengan respon yang baik (Ducoffe, 1995). Meningkatnya jumlah advertising dan semakin banyak serta cenderung ditayangkan kepada konsumen, tidak menutup kemungkinan adanya potensi konsumen merasa terganggu sehingga akan memberikan respon yang negatif terhadap iklan tersebut. Irritation pada sebuah iklan bersifat provokatif, mengakibatkan ketidakpuasan dan ketidaksabaran (D. A. Aaker \& Bruzzone, 1985).

\section{Youtube Advertising}

Menurut We Are Social dalam (kompas.com, 2016) rata rata pengguna televisi hanya menonton televisi 2 jam 22 menit perhari hal ini lebih sedikit di banding yang mengakses internet sebanyak 3 jam 33 menit perhari. Ini juga ditandai dengan biaya yang dikeluarkan oleh pengiklan dimana media digital dianggap jauh lebih murah dibandingkan beriklan di media televisi. Masih menurut We Are Social (2016) gambaran biaya penayangan iklan video digital adalah : a) Youtube: antara Rp39 juta sampai Rp100 juta per 100.000 views, jika iklan anda menarik maka biaya yang dikeluarkan akan semakin kecil (lebih hemat), b) Facebook Video, antara Rp6 juta sampai Rp13 juta sampai per 100.000 views, jika semakin menarik iklan tersebut semakin hemat biaya yang dikeluarkan.

\section{Brand Awareness}

Brand awareness merupakan bagian dari konsep brand equity yang diperkenalkan oleh David Aaker. Menurut Aaker (1991) Brand Awareness adalah kemampuan dari seseorang yang merupakan calon pembeli (potensial buyer) untuk mengenali (recognize) atau menyebutkan kembali (recall) suatu merek merupakan bagian dari 
suatu kategori produk. Terdapat 4 tingkatan brand awareness, yaitu:

1. Unware of Brand (tidak menyadari merek): yaitu tingkatan yang paling rendah dalam piramida kesadaran merek, dimana konsumen tidak menyadari akan adanya suatu merek.

2. Brand Recognition (pengenalan merek): yaitu tingkatan minimal dari kesadaran merek. Hal ini penting pada saat seorang pembeli memilih suatu merek pada saat melakukan pembelian.

3. Brand Recall (pengingatan kembali terhadap merek): yaitu pengingatan kembali terhadap merek didasarkan pada permintaaan seseorang untuk menyebutkan merek tertentu dalam suatu kelas produk. Hal ini bisa disebut juga dengan pengingatan kembali tanpa bantuan, karena berbeda dari tugas pengenalan, responden tidak perlu dibantu untuk memunculkan merek tersebut.

4. Top of Mind (puncak pikiran): yaitu apabila seseorang ditanya secara langsung tanpa diberi bantuan pengingatan dan orang tersebut dapat menyebutkan satu nama merek, maka merek yang paling banyak disebutkan pertama kali merupakan puncak pikiran. Dengan kata lain, merek tersebut merupakan merek utama dari berbagai merek yang ada didalam benak konsumen.

Ada 4 indikator yang dapat digunakan untuk mengetahui seberapa jauh konsumen aware terhadap sebuah brand: 1) Recall: yaitu sejauh mana konsumen bisa mengingat ketika ditanya merek apa saja yang diingatnya; 2) Recognition: yaitu sejauh mana konsumen mengenali merek tersebut termasuk dalam kategori tertentu; 3) Purchase: yaitu sejauh mana konsumen akan memasukkan suatu merek ke dalam alternatif pilihan ketika akan membeli produk/layanan; 4) Consumption: yaitu sejauh mana konsumen masih mengingat suatu merek ketika sedang menggunakan produk/ layanan pesaing
Kegunaan dari awareness ini dapat dilihat dari 4 nilai (value) yang diciptakan melalui brand awareness ini, yaitu:

1. Anchor to which other associations can be attached:brand awareness menyebabkan timbulnya asosiasi seseorang.

2. Familiarity /Liking: seseorang lebih menyukai sesuatu hal yang lebih familiar. Salah satu penjelasan hal tersebut adalah orang lebih membeli produk-produk yang terkategorikan low-involvement product.

3. Substance/commitment: dalam hal ini semakin tinggi awareness atas suatu nama produk menunjukkan bahwa semakin tinggi commitment dari brand tersebut.

4. Brand to consider: pada proses pembelian, langkah pertama yang dilakukan adalah dengan melakukan pemilihan terhadap sebuah alternatif. Pada proses ini, ketersediaan sebuah informasi menjadi sumber dari pemilihan tersebut. Proses recall menjadi penting, karena biasanya tidak banyak nama brand yang muncul pada proses ini. Brand pertama kali yang muncul di dalam benak seseorang akan mendapatkan keuntungan yang lebih besar dibandingkan dengan brand lainnya yang memiliki tingkat recall yang rendah.

\section{How to Achieve Brand Awareness?}

Hal yang bisa digunakan untuk meraih dan mempertahankan awareness sebagai berikut:

1. Be different, memorable: banyaknya pesan-pesan komunikasi pemasaran yang diterima oleh konsumen dalam kesehariannya, menyebabkan otak konsumen susah untuk dapat mengingat banyak pesan. Untuk itu penyampaian pesan yang berbedalah yang dapat diingat oleh target audience.

2. Involve a slogan or jingle: penggunaan slogan atau jingle bisa membantu untuk memvisualisasikan karakteristik dari produk perusahaan tersebut.

3. Symbol exposure: penggunaan simbol akan mempermudah konsumen mengenali suatu brand. 
4. Publicity: seseorang akan lebih tertarik mengetahui suatu berita baru daripada membaca iklan.

5. Event sponsorship: dalam suatu acara sponshorship yang berkesinambungan, bisa mempererat asosiasi suatu event terhadap suatu produk.

6. Consider brand extensions: menggunakan nama brand pada produk lain adalah salah satu cara untuk meningkatkan brand.

7. Using cues: menggunakan panduan dapat membantu mengarahkan ke kategori produk atau ke brand itu sendiri.

8. Recall requires repetition: membangun awareness membutuhkan pengulangan dan kontinuitas untuk bisa diingat oleh seseorang.

\section{Purchase Intention (Minat Beli)}

Purchase intention adalah suatu tahapan kecenderungan seseorang untuk bertindak sebelum keputusan membeli benar-benar dilaksanakan. Terdapat perbedaan antara pembelian aktual dan minat pembelian. Pembelian aktual adalah pembelian yang benar-benar dilakukan oleh konsumen, sedangkan minat pembelian adalah niat untuk melakukan pembelian pada kesempatan mendatang. Meskipun hanya berupa pembelian dimasa mendatang namun pengukuran terhadap minat pembelian dilakukan untuk memaksimalkan prediksi terhadap pembelian aktual itu sendiri. Dapat dikatakan bahwa minat beli adalah pernyataan mental dari seseorang yang merefleksikan rencana pembeliannya terhadap sejumlah produk dengan merek tertentu. Hal ini sangat diperlukan oleh para pemasar untuk mengetahui minat beli konsumen untuk memprediksi perilaku konsumen dimasa yang akan datang.

\section{Kerangka Penelitian}

Penggunaan iklan pada Youtube merupakan cara untuk memperluas jangkauan dari iklan. Saat iklan ditayangkan di Youtube, sebenarnya dapat menyasar pada pasar baru yang dapat berbeda dengan yang dilakukan dimedia lain, seperti: televisi dan radio. Iklan yang ditayangkan di Youtube kemudian diukur dengan 4 indikator, yaitu: informativeness, credibility, entertainment dan irritation. Saat iklan ditayangkan, maka sangat mungkin konsumen membayangkan atau teringat segala sesuatu yang terkait mengenai iklan tersebut, ini yang disebut dengan brand awareness. Pengenalan konsumen pada produk dapat mendorong terjadinya minat beli.

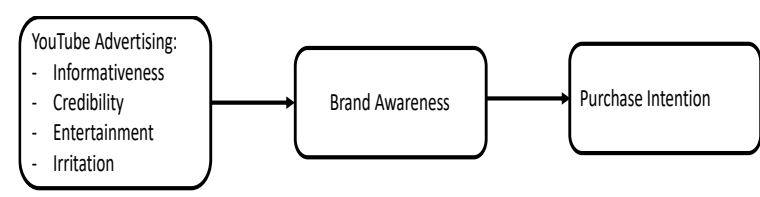

Gambar 1. Kerangka Penelitian

\section{Hipotesa Penelitian}

Hipotesa penelitian dalam penelitian ini adalah :
$\mathrm{H}_{1}$ : Informativeness berpengaruh terhadap brand awareness
$\mathrm{H}_{2}$ : Credibility berpengaruh terhadap brand awareness
$\mathrm{H}_{3}$ : Entertainment berpengaruh terhadap brand awareness
$\mathrm{H}_{4}$ : Irritation berpengaruh terhadap brand awareness
H5 : Brand awareness berpengaruh terhadap purchase intention

\section{METODE}

Rancangan penelitian dalam penelitian ini menggunakan riset deskriptif dalam bentuk single cross sectional. Riset deskriptif digunakan untuk memberikan gambaran fenomena yang diteliti secara apa adanya secara lengkap dan rinci. Peneliti menggunakan jenis riset ini karena dianggap dapat menggambarkan kondisi yang ada secara utuh dan mudah untuk dianalisa. Populasi dalam penelitian ini adalah masyarakat umum pengguna produk telekomunikasi pada iklan yang ditayangkan di Youtube. Pemilihan sampel secara spesifik berkaitan dengan kondisi khusus yang harus dipenuhi oleh responden, dimana responden adalah pengguna Youtube. Produk yang 
menjadi fokus penelitian adalah produk telekomunikasi yang banyak terdapat di iklan Youtube. Lokasi Penelitian dilakukan di Kota Palembang, dengan jumlah sampel sebanyak 200 orang. Menurut BPS, jumlah penduduk kota Palembang pada tahun 2014 sebesar 1.558.494 jiwa (BPS, 2015). Rincian komposisi berdasarkan usia dapat dilihat pada tabel 1:

Tabel 1. Jumlah Penduduk Kota Palembang dan Proporsi

\begin{tabular}{lrr}
\hline \multicolumn{1}{c}{ Kelompok usia } & $\begin{array}{c}\text { Jumlah } \\
\text { penduduk }\end{array}$ & Proporsi \\
\hline $\begin{array}{l}\text { Kelompok dibawah 19 } \\
\text { tahun (anak-anak) }\end{array}$ & 418,138 & $26.83 \%$ \\
$\begin{array}{l}\text { Kelompok usia 19-64 } \\
\text { tahun (pekerja aktif) }\end{array}$ & $1,079,793$ & $69.28 \%$ \\
$\begin{array}{l}\text { Kelompok usia >65 tahun } \\
\text { (senior citizen) }\end{array}$ & 60,563 & $3.89 \%$ \\
& $1,558,494$ & $100 \%$ \\
\hline
\end{tabular}

Sumber : BPS Indonesia (BPS, 2015), data diolah.

Untuk menarik sampel dari populasi, dalam penelitian ini digunakan penarikan sampel dengan metode Lemeshow. Penggunaan metode Lemeshow karena jumlah populasi persis tidak diketahui, sedangkan untuk estimasi (p) digunakan sebesar 15\%, serta alpha (sampling error) sebesar $5 \%$.

$$
\begin{aligned}
& n \\
& =\frac{Z^{2} \times \mathrm{P}(1-\mathrm{P})}{d^{2}}=\frac{1.96^{2} \times 0.15(1-0.15)}{0.05^{2}} \\
& n=\text { Jumlah sampel } \\
& z=\text { skor } z \text { pada kepercayaan } 95 \%=1,96 \\
& p=\text { estimasi (dalam penelitian ini estimasi } \\
& \text { yang digunakan sebesar } 15 \%) \\
& d=\text { alpha }(0,05) \text { atau sampling error }=5 \% \\
& \mathrm{~N}=195.9216 \text { (dibulatkan } 200 \text { responden). }
\end{aligned}
$$

Jumlah responden 200 orang juga mempertimbangkan telah mencukupi batas minimum untuk dilakukan analisis faktor. Metode dalam pengambilan sampelnya adalah non probability sampling yaitu setiap anggota populasi tidak memiliki peluang yang sama untuk terpilih menjadi sampel. Pemilihan sampel menggunakan purposive sampling yaitu dipilih sesuai dengan kebutuhan penelitian. Dalam perkembangan

\begin{tabular}{|c|c|c|c|}
\hline Variabel & Indikator & Referensi & Pengukuran \\
\hline \multirow{4}{*}{$\begin{array}{l}\text { Youtube } \\
\text { Advertising }\end{array}$} & -Informativeness & \multirow{4}{*}{$\begin{array}{l}\text { (Dehghani } \\
\text { et al., 2016) }\end{array}$} & \multirow{4}{*}{ Ordinal } \\
\hline & Credibility & & \\
\hline & -Intrusivness & & \\
\hline & Irritation & & \\
\hline \multirow{4}{*}{$\begin{array}{l}\text { Brand } \\
\text { Awareness }\end{array}$} & -Sadar akan eksistensi produk & \multirow{4}{*}{$\begin{array}{l}\text { (Kotler \& } \\
\text { Armstrong } \\
\text {, 2008) }\end{array}$} & \multirow{4}{*}{ Ordinal } \\
\hline & Mengetahui produk & & \\
\hline & Mengenali tanpa bantuan & & \\
\hline & Top of mind & & \\
\hline \multirow{4}{*}{$\begin{array}{l}\text { Purchase } \\
\text { Intention }\end{array}$} & -Mempertimbangkan untuk membeli & \multirow{4}{*}{$\begin{array}{l}\text { (Wilson, } \\
2003 \text { ) }\end{array}$} & \multirow{4}{*}{ Ordinal } \\
\hline & ·Berniat untuk membeli & & \\
\hline & -Kemungkinan akan membeli & & \\
\hline & -Selanjutnya akan membeli secara reguler & & \\
\hline
\end{tabular}
pengumpulan data, sampel yang terkumpul sebanyak 210 orang.

\section{Variabel Penelitian}

Variabel penelitian dan definisi operasional variabel dapat dilihat pada tabel 2 dan 3 berikut ini.

Tabel 2. Variabel Penelitian

Sumber: Data diolah dari berbagai sumber, 2018.

Tabel 3. Definisi Operasional

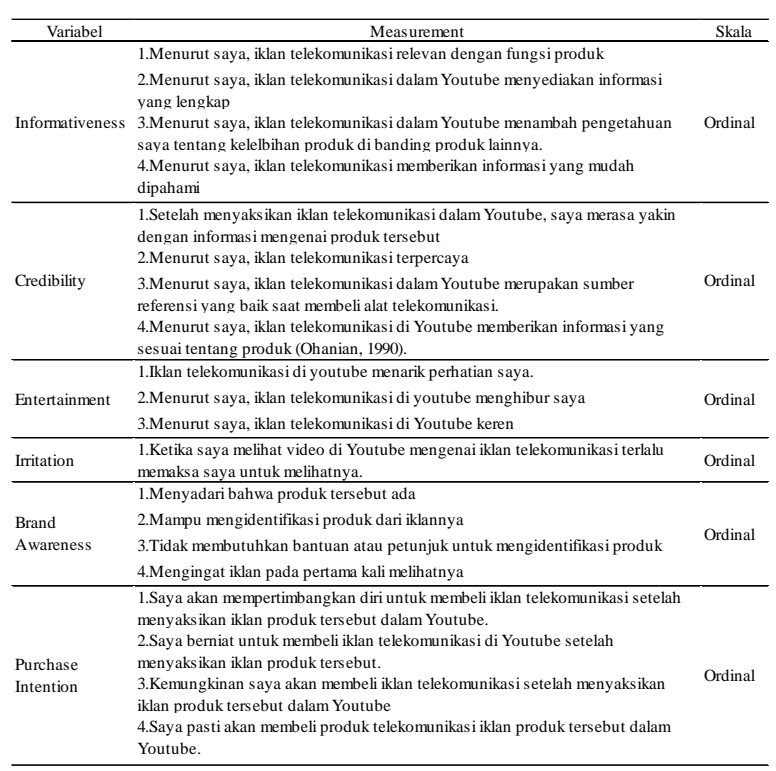

Sumber: Diolah dari berbagai sumber, 2018.

\section{Instrumen Penelitian}

Alat utama yang digunakan dalam penelitian ini adalah kuesioner yang dibagikan kepada responden untuk mencari data atau referensi yang berhubungan dengan penelitian ini. Pengumpulkan data dalam penelitian ini digunakan menggunakan teknik survei dengan penggunaan kuesioner 
untuk mengetahui jawaban dari responden. Rentang skala pengukuran yang digunakan adalah 1-6.

\section{Teknik Analisis Data}

Teknik analisis data yang digunakan oleh peneliti dalam penelitian ini adalah structural equation modelling, dimana akan menguji hubungan dan pengaruh antar variabel. Responden pada saat mengisi kuesioner diperlihatkan terlebih dahulu setiap iklan yang akan diukur, data dari jawaban konsumen diinput kedalam program komputer. Data yang telah diinput kemudian dilakukan analisis structural equation. Untuk membantu analisis statistik, digunakan program yaitu SPSS versi 22 dan AMOS versi 22.

\section{HASIL DAN PEMBAHASAN}

Tabel 4. Profil Responden

\begin{tabular}{|c|c|c|c|c|}
\hline \multicolumn{5}{|c|}{ Profil Responden } \\
\hline Jenis Kelamin & $\begin{array}{c}\text { Status } \\
\text { Perkawinan }\end{array}$ & $\begin{array}{c}\text { Pendidikan } \\
\text { Terakhir }\end{array}$ & Profesi Utama & $\begin{array}{l}\text { Rata-rata } \\
\text { Pengeluaran } \\
\text { Perbulan }\end{array}$ \\
\hline $\begin{array}{c}\text { Jenis kelamin } \\
\text { responden laki- } \\
\text { laki sebesar } 86 \\
\text { orang atau } 41 \% \\
\text { dan responden } \\
\text { perempuan } \\
\text { sebesar } 124 \\
\text { orang atau 59\%. }\end{array}$ & $\begin{array}{c}\text { Status } \\
\text { perkawinan } \\
\text { responden yang } \\
\text { mendominasi } \\
\text { adalah yang } \\
\text { belum menikah } \\
\text { sebanyak } 140 \\
\text { orang atau } \\
67.1 \% \\
\text { responden. }\end{array}$ & $\begin{array}{c}114 \text { orang } \\
\text { responden atau } \\
\text { sebanyak } 54.3 \% \\
\text { Pendidikan } \\
\text { terakhir } \\
\text { responden adalah } \\
\text { SMU/ sederajat. }\end{array}$ & $\begin{array}{c}130 \text { orang } \\
\text { responden atau } \\
\text { sebanyak } 61.9 \% \\
\text { merupakan } \\
\text { kalangan } \\
\text { mahasiswa. }\end{array}$ & $\begin{array}{c}\text { sebanyak } 70 \\
\text { orang responden } \\
\text { atau sebanyak } \\
33.7 \% \\
\text { mempunyai } \\
\text { tingkat } \\
\text { pengeluaran } \\
\text { perbulan }<1 \text { juta. }\end{array}$ \\
\hline
\end{tabular}

Sumber: Data diolah, 2018

Tabel 5. Perilaku Responden

\begin{tabular}{|c|c|c|c|c|}
\hline \multicolumn{5}{|c|}{ Perilaku Responden } \\
\hline $\begin{array}{l}\text { Rata-rata waktu } \\
\text { mengakses } \\
\text { youtube per hari }\end{array}$ & $\begin{array}{l}\text { Tujuan } \\
\text { mengakses } \\
\text { youtube }\end{array}$ & $\begin{array}{l}\text { Apakah iklan } \\
\text { youtube } \\
\text { mengganggu? }\end{array}$ & $\begin{array}{l}\text { Sebisa mungkin } \\
\text { iklan saya "Skip" } \\
\text { Sebisa mungkin } \\
\text { iklan saya "Skip" }\end{array}$ & $\begin{array}{l}\text { Iklan yang tidak } \\
\text { bisa di skip itu } \\
\text { menjengkelkan }\end{array}$ \\
\hline $\begin{array}{l}\text { sebanyak } 96 \\
\text { orang responden } \\
\text { atau sebanyak } \\
45.7 \% \\
\text { mengakses } \\
\text { Youtube }<1 \text { jam } \\
\text { perhari. }\end{array}$ & $\begin{array}{l}110 \text { orang } \\
\text { responden atau } \\
\text { sebanyak } 52.4 \% \\
\text { mengakses } \\
\text { Youtube sebagai } \\
\text { Hiburan } \\
\text { (menoton music, } \\
\text { cuplikan video, } \\
\text { dll) }\end{array}$ & $\begin{array}{l}186 \text { orang } \\
\text { responden atau } \\
\text { sebanyak } 88.6 \% \\
\text { menganggap } \\
\text { iklan yang } \\
\text { muncul } \\
\text { mendahului video } \\
\text { yang ingin } \\
\text { ditonton sebagai } \\
\text { iklan yang } \\
\text { mengganggu. }\end{array}$ & $\begin{array}{l}194 \text { orang } \\
\text { responden atau } \\
\text { sebanyak } 96.2 \% \\
\text { akan melakukan } \\
\text { "skip" terhadap } \\
\text { iklan yang } \\
\text { muncul di media } \\
\text { Youtube. }\end{array}$ & $\begin{array}{l}170 \text { orang } \\
\text { responden atau } \\
\text { sebanyak } 81 \% \\
\text { tidak menyukai } \\
\text { iklan yang tidak } \\
\text { bisa di "skip" di } \\
\text { media Youtube. }\end{array}$ \\
\hline
\end{tabular}

Sumber: Data diolah, 2018
Tabel 6. Analisis 6 SEM

\begin{tabular}{|l|rrrrr|}
\hline & Estimate & S.E. & C.R. & P & Keterangan \\
\hline BA <--- Informativeness &,- 041 &, 046 &,- 882 &, 378 & Insign. \\
BA <--- Credibility &, 228 &, 119 & 1,920 &, 055 & Insign. \\
BA <--- Entertaiment &, 052 &, 034 & 1,532 &, 126 & Insign. \\
BA <--- Irritation &, 001 &, 012 &, 084 &, 933 & Insign. \\
PI <--- BA & 3,375 & 1,454 & 2,321 &, 020 & Sign. \\
\hline
\end{tabular}

Sumber: data diolah, 2018.

Berdasar hasil analisa data pada tabel 6 diperoleh hasil:

a. Informativeness tidak berpengaruh terhadap brand awareness.

Menurut (Ducoffe, 1995), informativeness akan mempengaruhi perhatian pelanggan dan dapat memberikan nilai tambah sebuah berita tambah atau dapat terhubung dengan kognisi kebutuhan pelanggan. Ketika berita atau pesan mencakup kebutuhan pelanggan, pelanggan menikmati iklan tersebut dengan seksama/detail. Pelanggan berkonsentrasi pada pesan dan tidak melewatkan kesempatan mengenai informasi produk. Dalam penelitian ini, dapat dilihat bahwa responden menganggap bahwa iklan yang ada di Youtube tidak dianggap memberi nilai tambah terhadap kebutuhan pelanggan. Apabila pelanggan menikmati informasi pada iklan tersebut tentunya responden akan berkonsentrasi terhadap iklan yang ditayangkan dan melihat secara detail iklan yang muncul dilayar Youtube. Hal tersebut memberi indikasi bahwa informativeness bukan faktor yang menimbulkan kesadaran responden akan sebuah merek.

b. Credibility tidak berpengaruh terhadap brand Awareness.

Menurut (Mackenzie et al., 1989), kredibilitas iklan mengacu pada kebenaran yang dirasakan dan kepercayaan dari iklan yang ditayangkan. Kredibilitas iklan sering dipengaruhi oleh kredibilitas perusahaan atau sejauh mana pelanggan percaya bahwa perusahaan dapat merancang dan memberikan produk dan layanan yang memenuhi kebutuhan pelanggan (S. M. Choi \& Rifon, 2002). Dalam penelitian ini, dapat 
dilihat bahwa responden tidak terlalu memikirkan kredibilitas dari perusahaan yang beriklan untuk menimbulkan kebenaran dan kepercayaan dari produk yang diiklankan. Kredibilitas sumber adalah tingkat keahlian dan kepercayaan konsumen pada sumber pesan. Hal ini mengindikasikan bahwa credibility bukan faktor yang menimbulkan kesadaran responden akan sebuah merek.

c. Entertainment tidak berpengaruh terhadap brand awareness.

Iklan yang menyenangkan dapat menarik perhatian penerima (Ducoffe, 1995). Iklan yang menghibur dapat mengalihkan minat pelanggan, waktu berlalu dengan cepat. Selama interaksi dengan iklan, pelanggan terfokus dan tidak memikirkan hal lain (Hoffman, Novak, \& Peralta, 1996).

Dalam penelitian ini, dapat dilihat bahwa responden berpendapat bahwa iklan yang terdapat di Youtube tidak bersifat menghibur sehingga responden tidak terlalu fokus pada iklan yang ditayangkan. Hal ini mengindikasikan bahwa entertainment bukan faktor yang menimbulkan kesadaran responden akan sebuah merek.

d. Irritation tidak berpengaruh terhadap brand awareness.

The Merriam-Webster Dictionary menyatakan bahwa iklan menjengkelkan adalah iklan yang memancing dan menyebabkan ketidaksenangan dan ketidaksabaran pelanggan. Iritasi dalam iklan mengurangi efektivitas iklan (D. A. Aaker \& Bruzzone, 1985). Ketika iklan menggunakan teknik yang menjengkelkan dan terlalu manipulatif, pelanggan tidak akan menganggap iklan sebagai pengaruh yang menguntungkan (Ducoffe, 1995). Iklan interaktif yang ada di Youtube mungkin mengganggu dan dapat memberikan banyak sekali informasi dan dianggap sebagai ancaman bagi privasi pelanggan (Stewart \& Pavlou, 2002). Iklan yang menjengkelkan menimbulkan kekesalan dan ketidaksabaran bagi penonton
(Ducoffe, 1995). Sejumlah besar informasi dan interaktivitas iklan dapat mengalihkan perhatian pemirsa yang lagi fokus pada pekerjaan (Stewart \& Pavlou, 2002). Untuk menghindari hal tersebut maka biasanya browser Web Chrome menambahkan opsi "Lompati iklan di Youtube" untuk melewatkan iklan (Cozma, 2012). Ini menunjukkan bahwa pengguna mungkin tidak ingin iklan menjengkelkan. Pilihan meninggalkan halaman itu dan berlanjut ke tujuan berikutnya tujuan melihat Youtube. Pesan yang mengganggu dapat mengganggu dan menghambat konsentrasi pelanggan. Dalam penelitian ini, dapat dilihat bahwa responden menganggap bahwa untuk iklan yang terdapat di Youtube tidak terlalu menjengkelkan. Hal ini mengindikasikan bahwa irritation bukan faktor yang menimbulkan kesadaran responden akan sebuah merek.

e. Brand awareness berpengaruh terhadap purchase intention.

Dari analisa data yang dilakukan bahwa, iklan yang intens dengan berbagai macam bentuk iklan itu sendiri dapat meningkatkan kesadaran terhadap merek sebuah produk. Menurut Freddy Rangkuti (2009:39), Brand awareness merupakan kemampuan calon pembeli atau konsumen mengenali ataupun mengingat sebuah merek. Hal ini meliputi nama, gambar/logo, serta slogan tertentu yang digunakan pemasar untuk mempromosikan produk-produknya. Brand awareness adalah salah satu faktor penting untuk memperkuat brand sebuah produk. Semakin konsumen dapat mengingat brand produk, maka semakin besar pula intensitas pembelian yang akan dilakukan. Hal ini terbukti bilamana, responden mengenal secara baik merek sebuah produk maka dapat menimbulkan minat beli. Dengan mengenal produk tersebut, konsumen berharap bahwa produk yang dibelinya akan sesuai dengan harapan yang diinginkan. 


\section{Kesimpulan}

Berdasar hasil analisa data dapat disimpulkan beberapa hal: 1) Informativeness tidak mempunyai pengaruh terhadap brand awareness, 2) Credibility tidak mempunyai pengaruh terhadap brand awareness, 3) Entertainment tidak mempunyai pengaruh terhadap brand awareness, 4) Irritation tidak mempunyai pengaruh terhadap brand awareness, 5) Brand awareness mempunyai pengaruh terhadap purchase intention.

\section{DAFTAR PUSTAKA}

Aaker, D. (1991). Managing Brand Equity. New York: The Free Press.

Aaker, D. A., \& Bruzzone, D. E. (1985). Causes of Irritation in Advertising. Journal of Marketing, 49(2), 47.

Balasubramanian, S., Peterson, R. A., \& Jarvenpaa, S. L. (2002). Exploring the implications of M-commerce for markets and marketing. Journal of the Academy of Marketing Science, 30(4), 348-361.

BPS, B. P. S. I. (2015). Jumlah Penduduk kota Palembang, berdasarkan usia. Jakarta, Indonesia.

Choi, K. Y., Hwang, J.-S., \& McMillan, S. J. (2010). Consumer Perceptions of Online Shopping Environments. Psychology \& Marketing, 30(6), 461469.

Choi, S. M., \& Rifon, N. J. (2002). Antecedents and Consequences of Web Advertising Credibility Credibility: A Study Of Consumer Response To Banner Ads, (April 2015), 37-41.

Cozma, N. (2012). How to skip ads on Youtube. CNET: CBS Interactive Inc.

Dehghani, M., Niaki, M. K., Ramezani, I., \& Sali, R. (2016). Evaluating the influence of Youtube advertising for attraction of young customers. Computers in Human Behavior, 59, 165-172.

Ducoffe, R. H. (1995). How consumers assess the value of advertising. Journal of Current Issues and Research in Advertising, 17(1), 1-18.

Haghirian, P., Madlberger, M., \&
Tanuskova, a. (2005). Increasing Advertising Value of Mobile Marketing - An Empirical Study of Antecedents. Proceedings of the 38th Annual Hawaii International Conference on System Sciences, 00(C), 1-10.

Hoffman, D. L., Novak, T. P., \& Peralta, M. (1996). Building Con Trust Online, 42(4).

Khan, M. L. (2017). Social media engagement: What motivates user participation and consumption on Youtube? Computers in Human Behavior, 66, 236-247.

https://www.kompasiana.com/oktaviaorp/pe ngiklanan-pre-roll-advertising-dalammedia-sosial-Youtube

kompas.com. (n.d.-b). Pengiklanan Pre-Roll Advertising Dalam Media Sosial Youtube oleh Oktavia R Pahlawati Kompasiana.

Kompas.com. (2016). Perubahan Trend Iklan di Indonesia Tahun 2016.

Kotler, P., \& Armstrong, G. (2008). Principles of Marketing, 12th Edition. Upper Saddle River, New Jersey: Pearson Education, Inc.

Limbu, Y. B., Huhmann, B. a., \& Peterson, R. T. (2012). An examination of humor and endorser effects on consumers' responses to direct-to-consumer advertising: The moderating role of product involvement. International Journal of Pharmaceutical and Healthcare Marketing, 6(1), 23-38.

Linn Fingalsson, Katalina Palma, S. S. (2015). Attitude is everything. Thesis, 383-384.

Liu, C. L. E., Sinkovics, R. R., Pezderka, N., \& Haghirian, P. (2012). Determinants of Consumer Perceptions toward Mobile Advertising - A Comparison between Japan and Austria. Journal of Interactive Marketing, 26(1), 21-32.

Mackenzie, S. B., Lutz, R. J., Belch, G. E., \& Mackenzie, S. B. (1989). Attitude Advertising Effectiveness: A Competing Explanations Test, 23(2), 130-143.

McQuail, D. (2010). McQuail's Mass 
Communication Theory. SAGE

Publications.

Ohanian, R. (1990). Construction and Validation of a Scale to Measure Celebrity. Journal of Advertising, 19(3), 39-52.

Pavlou, P. A., \& Stewart, D. W. (2000). Measuring the Effects and Effectiveness of Interactive Advertising. Journal of Interactive Advertising, 1(1), 61-77.

Rangkuti, Freddy. ((2009). Strategi Promosi yang Kreatif dan Analisis Kasus Integrated Marketing Communication. Jakarta : PT. GramediaPustakaUtama

Setiawan, S. R. D. (2017). Tahun 2017, Pengguna Internet di Indonesia Mencapai 143,26 Juta Orang. Kompas.Com. Retrieved from https://ekonomi.kompas.com/read/2018/ 02/19/161115126/tahun-2017pengguna-internet-di-indonesiamencapai-14326-juta-orang

Stewart, D. W., \& Pavlou, P. A. (2002). From Consumer Response to Active Consumer: Measuring the Effectiveness of Interactive Media. Journal of the Academy of Marketing Science, 30(4), 376-396.

Varshney, U., \& Vetter, R. O. N. (2002). Mobile Commcerce: Framework, Applications and Networking Support. Mobile Networks and Applications, 7, 185-198.

Venkatesh, V., Ramesh, V. and Massey, A. P. (2003). Understanding U Sability in Mobile Commerce, 46(12), 53-56.

Wilson, S. (2003). The Effect of Music on Perceived Atmosphere and Purchase Intentions in a Restaurant. Psychology of Music, 31(1), 93-112.

Zeithaml, V. a. (1988). Consumer Perceptions of Price, Quality, and Value- A Means-End Model and Snthesis of Evidence. Journal of Marketing. 